\title{
THE ROLE OF -(s)I IN TURKISH INDEFINITE NOMINAL COMPOUNDS
}

\author{
Erhan Aslan \\ Asli Altan
}

\begin{abstract}
This paper intends to clarify the distinction between the third person possessive suffix -(s)I attached to nouns to indicate possession and the compound marker, CM, (s)I used to construct lexicalized nominal compounds by stating their basic semantic and structural differences. To demonstrate the lexicalizing effect of the CM attached to nominal compounds, fifty native Turkish speakers irrespective of age, gender, and educational background were administered a questionnaire. In this questionnaire some nominal compounds, either the head or the modifier parts of which were imparted as blanks, were given to these subjects and they were asked to fill in the blanks with appropriate words. The aim was to find out whether some nominal compounds were more lexicalized than others. The analysis revealed that (s)I in nominal compounds functions as a compounding marker rather than indicating possession and it has the effect of lexicalizing these compound structures.
\end{abstract}

Key words: Nominal compounds, compound marker, third person possessive suffix, lexicalization

\section{TÜRKÇE BELIRTISİZ AD TAMLAMALARINDAKİ-(s)I EKININN GÖREVI $\ddot{O} z e t$}

Bu araştırmada, adlara eklenerek iyelik anlamı belirten üçüncü kişi iyelik eki-(s)I ile ad tamlamaları oluşturmada kullanılan ve bu tamlamalara sözcük görevi yükleyen tamlama eki

-(s)I arasındaki temel anlamsal ve yapısal farklar açıklanmaya çalışılmıştır. Tamlama ekinin eklendiği tamlamaları sözlükselleştirme etkisini ortaya koymak için, anadili Türkçe olan elli kişiye bir sormaca uygulanmıştır. Katılımcıların yaşı, cinsiyeti ve eğitim durumu göz ardı edilmiştir. Bu sormacada, bazı ad tamlamalarının tümleyen veya tümlenen sözcükleri boşluk olarak verilmiş ve katılımcılardan bu boşlukları uygun sözcüklerle doldurmaları istenmiştir. Bu çalışma, bazı ad tamlamalarının diğgerlerine oranla daha fazla sözlükselleşmiş olup olmadı̆̆ını ortaya koymayı amaçlamıştır. Çalışmanın sonucunda, belirtisiz ad tamlamalarına eklenen -(s)I ekinin iyelik ekinden çok aslında tamlama eki olduğu ve eklendiği ad tamlamalarına sözcük durumu kazandırdı̆̆ saptanmıştır.

Anahtar sözcükler: Ad tamlamaları, tamlama eki, üçüncü şahıs iyelik eki, sözlükselleşme. 


\section{INTRODUCTION}

Turkish has a number of ways to form compound structures such as nominal compounds, adjectival compounds, and verbal compounds. Of all these different types of compounds, nominal compounds are the most productive and they make a substantial contribution to the expansion of the lexicon of Turkish due to their wordlike characteristics.

There are two basic types of nominal compounds. One is called 'bare compounds' which, as Göksel and Kerslake (2005:102) define, 'are composed of two juxtaposed nouns with no suffixation to mark the relation between them.' (e.g. klz kardeş 'sister', Ingiliz yazar 'British writer', altın bilezik 'golden bracelet', anneanne 'grandmother', anayasa 'constitution'). The second type is 'compounds with CM' (compound marker henceforth) in which there are two nouns to the first of which no suffix is attached whereas the following noun is suffixed with CM -(s)I (e.g. diş firçası 'tooth brush', dilbilgisi 'grammar', devekuşu 'ostrich', ders kitabl 'course book'). In both types of these nominal compounds, the first component defines or limits the meaning of the second component, which functions as the head of the compound (Banguoğlu, 1998:332). As might be observed from the above mentioned examples, in both types some compounds are written as one word whereas some are not. Nevertheless, the resulting structures constructed by both types of compounding refer to a certain entity, thus, they are treated as unique lexical items.

Compounds with CM are used in a number of ways. Primarily, they refer to a certain entity (e.g. ayakkabl 'shoe', yemek odasl 'dining room'). They also denote different varieties of a certain kind, where the first element specifies the type of the head (e.g. arıkuşu 'bee-eater', devekuşu 'ostrich'; çörekotu 'black cumin', ökseotu 'mistletoe'; toplum bilimi 'sociology', anlam bilimi 'semantics'). They can also signify such geographical places as cities, mountains, lakes or rivers (e.g. Ankara şehri 'Ankara city', Van Gölü 'Lake Van', Toros Dağlart 'Toros Mountains'). Compounds with $\mathrm{CM}$ are also used to denote something which is peculiar to a specific nation or city (e.g. Türk kahvesi 'Turkish coffee', Malatya kaylsısı 'Malatya apricot') and certain kinds of professions (ev hanımı 'housewife', banka müdürü 'bank manager').

After this brief explanation about Turkish nominal compounds, we will move on to the basic characteristics of compounds with $\mathrm{CM}$ which is the focus of this paper. As a 
first step, it would be convenient to take a look at the previous analyses and descriptions about nominal compounds with $\mathrm{CM}$.

\section{REVIEW OF LITERATURE}

\subsection{Some Preliminaries}

Nominal compounds in Turkish, or in its most traditional definition 'izafet' constructions, which are termed as 'adtakımı' by Banguoğlu (1998:331-39) or 'ad tümlemesi' by Gencan (1979:135) have been traditionally divided into two sub-sets: 'the definite nominal constructions' which are also known as genitive-possessive constructions (e.g. sokağın sonu 'the end of the street') and 'indefinite nominal constructions' which are also labeled as 'possessive compounds' (e.g. bulaşık makinesi 'dishwasher', buzdağ 'iceberg') as is also stated by Hayasi (1996). According to Kornfilt (1997:474), of these two types of so-called 'izafet' constructions, the more widespread pattern is the indefinite nominal compounds, the second constituent of which carries the CM -(s)I. As Schaaik (2001:146) states, -(s)I in indefinite nominal compounds is identical in form with the third person singular possessive (3PsPOSS henceforth) suffix. However, they bear some differences in function. Since the major purpose of this paper is to put forward the basic functional distinctions between the 3PsPOSS suffix and the CM, it would be appropriate to review the relevant literature about the ways that -(s)I is treated in indefinite nominal compounds.

-(s)I in indefinite nominal compounds has been recognized as the 3PsPOSS suffix by many grammarians (e.g. Banguoğlu, 1998; Gencan, 1979; Lewis, 1967; Underhill, 1976). However, some of them such as Banguoğlu (1998) or Underhill (1976) state that the 3PsPOSS suffix does not establish a possessive relationship between the components constituting the compound. This assumption is also well expressed by Lewis (1967:42): 'The indefinite izafet is used when the relationship between the two elements is merely qualificatory and not so intimate or possessive as indicated by the definite izafet.'

However, -(s)I in indefinite nominal compounds is treated by some grammarians as a unique compound marker. Schroeder (1999:133) regards -(s)I as 'compoundmarking function of the 3PsPOSS suffix defining it as a derivational device to form nominal compounds.' Likewise Swift (1963:133) points out that the 3PsPOSS suffix in nominal compounds functions 'not as a referent to a specific third person who possesses the item denoted by the nominal to which it is suffixed, but rather functions as a signal of the compounding itself.' 
The idea that some nominal compounds with CM have come to bear a substantive base and these structures are assigned a lexical status has been favored by many researchers. As Kornfilt (1997:474) suggests, 'some of the compounds bearing the CM are frozen and have become a single word.'

In the light of the different views concerning the status of $-(\mathrm{s}) \mathrm{I}$ in indefinite nominal compounds, it is safe to suggest that there is a dilemma in the treatment of (s)I in indefinite nominal compounds: some assume it as the functional extension of the 3PsPOSS suffix while others regard it as a unique CM. If so is the case then the following question needs to be addressed: Do these two treatments about $-(\mathrm{s}) \mathrm{I}$ in Turkish nominal compounds bear any difference or are they simply two different terminologies used for the same structural strata? This paper will attempt to suggest answers to this question in the following section.

\subsection{The Differences between the 3PsPOSS Suffix and the CM}

The 3PsPOSS suffix (and of course other possessive suffixes differing in person and number) can be used in combination with a noun in the genitive case (Underhill, 1976: 92).

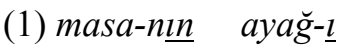 \\ GEN 3PsPOSS}

'the foot of the table'

In this example there are two lexical entities which are semantically tied to each other through a possessive relationship. The first constituent of the phrase is the 'possessor' of the second one and the other which is the 'possessed' refers to the entity possessed by the first constituent.

A CM affixed noun, on the other hand, is not a part of a genitive construction. The CM merely builds up a nominal compound the constituents of which do not have a semantic possessor-possessed relationship (Underhill, 1976). The following examples illustrate that the addition of the genitive marker to the compound noun yields to ungrammaticality:

(2) bal mum- $\iota$ $\mathrm{CM}$

(3) kan kardeş- $\underline{-}$ *bal-ın mum- $-\underline{u}$

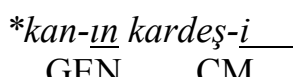

'bee's-wax'

'blood brother' 
The above nominal compounds bearing the $\mathrm{CM}$ do refer to one lexical entity though they consist of two separate lexical items. In such compounds the lexical entity being referred to is always signified by the second constituent which is the 'head' of the compound. The first constituent which is the 'modifier' of the compound simply acts as specifying or restricting the meaning of the second constituent.

Thus, this paper argues that the 3PsPOSS suffix forms nominal phrasal constructions which do not have substantive basis. However, the CM forms nominal compounds which refer to one simple lexical item, as can be observed from the following examples:

(4) akşam yeme ğ- $\quad$ 'dinner'

$\mathrm{CM}$

(5) otobüs durăg- $\underline{\text { - }} \quad$ 'bus-stop'

$\mathrm{CM}$

3PsPOSS suffix (and of course other forms of possessive suffixes) must obligatorily be present in any genitive-possessive construction and cannot be omitted regardless of the type of suffix attached to the compound ${ }^{1}$.

(6) Ali’nin gömleğ-ị burada. *Ali'nin gömlek burada.

$$
\text { GEN 3PsPOSS }
$$

'Ali's shirt is here'.

However, there are some environments in which the $\mathrm{CM}$ in nominal compounds drops (Hayasi, 1996):

a) When the possessive suffix is attached to a nominal compound:

1 As suggested by Göksel and Kerlaske (2005: 184), in informal styles, the possessive suffix can be deleted in some cases where the genitive modifier is a first or second person pronoun.

(1) Bizim çocuk yine hastalandl. 'Our kid is sick again'

GEN 
(7) evrak çanta-sl$\underline{\mathrm{CM}}-\begin{aligned} \text { evrak çanta-m } \\ 1 \text { sPPOSS }\end{aligned}$ 'briefcase'

$$
\begin{aligned}
& \mathrm{CM} \quad 1 \text { PsPOSS } \\
& \text { _ evrak çanta-n } \\
& \text { 2PsPOSS } \\
& \text { _ evrakçanta-s- } \underline{\underline{l}} \\
& \text { 3PsPOSS }
\end{aligned}
$$

b) When the derivational suffix -1I is attached to a nominal compound:

(8) domates salça-š__ domates salça-ll yemek

$$
\mathrm{CM}
$$

'tomato paste' _ 'dish with tomato paste'

c) When some nominal compounds become a component of another nominal compound:

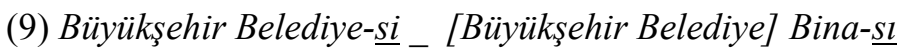

$$
\mathrm{CM} \quad \mathrm{CM}
$$

'Metropolis Municipality'_ The Building of Metropolis Municipality'

The 3PsPOSS suffix makes the noun to which it is attached acquire a definite/referential status whereas the CM makes the nominal compound obtain an indefinite/non-referential status.

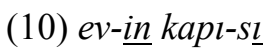

$$
\text { GEN 3PsPOSS }
$$

'the door of the house'

[DEFINITE / REFERENTIAL]

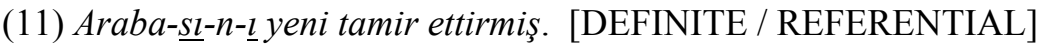
3PsPOSS ACC

'He has just had his car repaired.'

(12) ev kapl-sl [INDEFINITE/ NON-REFERENTIAL]

$$
\mathrm{CM}
$$

'the house door' 
One of the ways to make the nominal compound with $\mathrm{CM}$ have a definite/referential status is to suffix the accusative marker to the second constituent of the compound.

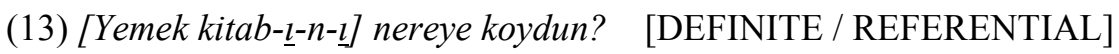
$\mathrm{CM}$ ACC

'Where did you put the cookbook?'

\section{METHODOLOGY}

\subsection{Subjects}

In this study a questionnaire was administered to fifty Turkish native speakers living in Ankara, Turkey. The participation in filling the questionnaire was on voluntary basis. The average age of the participants was 27 . Most subjects did have a university degree. A few high school students were also included in the study. The gender of the participants was disregarded. The only criterion crucial for involvement has been the subject's being native speakers of Turkish. All fifty participants speak Turkish as their mother tongue.

\subsection{Procedure}

During the course of the study, subjects were asked to fill in the questionnaire individually. Each subject was informed that there was a time limit which was 10 to 15 minutes. Apart from the instructions included at the beginning of each section of the questionnaire, a few of the subjects who had difficulty in filling some parts of the questionnaire were provided with some further explanation. Subjects unable to fill some of the blanks were tolerated. Since there is a dispute about whether some nominal compounds should be written as one word or two words, both forms were accepted. That is, for words that are controversial as evkadinı 'housewife', yayınevi 'publishing house' or yer elmast 'Jerusalem artichoke' both the spelling as two words or one word received the same score.

For the reliability of the results, each subject was observed by the researchers during the implementation of the questionnaire. The time and place in which the questionnaire was carried out depended upon the subjects, that is, the questionnaire was conducted in different times and different places. All in all, the implementation of the questionnaire took approximately two weeks. 


\subsection{Questionnaire}

The questionnaire which was prepared by the authors aimed at measuring whether some indefinite nominal compounds in Turkish became lexical units. As can be observed in Appendix A, the questionnaire was made up of five sections. The first three sections included some nominal compounds either the head or the modifier parts of which were given as blanks. The subjects were asked to fill in these blanks with appropriate words in order to form nominal compounds. The first section consisted of 30 indefinite nominal compounds which must be written as single words; the second one contained 10 definite nominal compounds; and the third section involved 30 indefinite nominal compounds the components of which were supposed to be separate. In each section there were 12 items where the subjects had to find the head of the compound.

The fourth section was composed of 5 questions. Each question had two identical nominal compounds differing only in the position of an adjective. In this part the subjects were asked to select which one they would prefer to use in their everyday speech. Finally, in the fifth section the subjects were asked which nominal compounds that they had constructed in the first and the third sections might be assumed to be a lexical item referring to a certain object or entity.

For ease of the implementation of the questionnaire, the subjects were provided with two examples to direct them at the beginning of the first three sections. However, in the fourth and fifth sections no example was given since examples to be given in those sections would have affected the answers.

During the course of collecting nominal compounds to be included in the questionnaire, the authors referred to a number of Turkish grammar books (eg. Lewis, 1967; Schroeder, 1999; Banguoğlu, 1998; Gencan, 1979; Underhill, 1976; Göksel and Kerslake, 2005) as well as consulting other Turkish native speakers for more examples.

For the reliability of the study, the questionnaire was administered to five subjects in a pilot study and necessary amendments were made - some nominal compounds were excluded, new ones were added.

\section{ANALYSIS and RESULTS}

In this section the answers of the participants will be analysed.

\subsection{Results of Section A:}

The results indicated that some compounds were guessed correctly by more than $50 \%$ of the participants. A total of 10 words reached a recall rate higher than $50 \%$. This suggests that these phrases act as a unit where one word triggers the other word in the memory. 
A total of 30 words were given in the first section and the subjects were told that these nominal compounds are written as one word. It is interesting to note that there is no word which was correctly guessed by all of the participants. There seems to be a difference in the recall rates depending on whether it was the head or the modifier that was given. It was easier for the subjects to determine the modifier rather than the head. As can be observed from Table 1, in all the words with high recall rate, 9 out of 10 items were the ones where the head was given and the modifier was asked. It is observed that the percentage of correct guessing is lower in cases where the modifiers were given. In all the tokens which reached $80 \%$ or more correct recall rate, the head had been provided and the subjects were asked to find the modifier. This reveals the dominant nature of the head in nominal compounds.

These results demonstrate that some noun compounds with $\mathrm{CM}$ are treated as collocations. In words like ayakkabl 'shoe', denizatı 'sea horse', buzdolabl 'refrigerator', milletvekili 'member of parliament', where the correct answer percentage is around $80 \%$, there was no wrong answer. The subjects either provided the correct answer or left the blanks unfilled.

In words like 'dışişleri' 'foreign affairs' there are many other choices for the first word. However, the fact that $50 \%$ of the subjects chose the modifier ' $d$ ls' among all the other possibilities, shows that these words are collocations of each other. In this respect, collocation can be defined as the sequence of words or terms which co-occur more often than will be expected by chance (McCarthy and O'Dell, 2002:12). This is exactly the case with 'dişişleri' since collocation is concerned with the way words occur together. Native speakers are used to seeing these words together, and thus they form a collocation unit.

Another crucial point to note is that even though some nominal compounds did not reach high percentages, the same set of answers were provided by the subjects. To illustrate, when the head dağ 'mountain' was given, all answers accumulated around 4

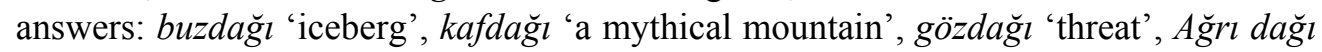
'Ağr1 Mountain'. Likewise, when the head of the nominal compound was given as burnu 'nose; cape', 5 answers were provided by subjects: kuşburnu 'rosehip', arıburnu 'Cape of Ar1', kargaburnu 'nose of a crow', ümitburnu 'Cape of Hope', zeytinburnu 'a place name'. When the modifier göz 'eye' was given, the answers were mostly between 4 possible combinations: gözbebeği 'iris', göznuru 'visual faculty', gözdağ 'threat', gözaltı 'custody'. It is also worth noting that the subjects came up with the same answer gözdăgl 'fright' whether they were asked to find the modifier of dağ 'mountain' or the head of göz 'eye'. 
The most distinct answers appeared when the head baş 'head' was given and the subjects were asked to find the modifier: kuşbaşs 'small pieces of casseroled meat', dağbaşı 'mountain top; remote place', gölbaşı 'a place name', gelinbaşı 'hair of a bride', elebaşı 'gang leader', subaşı 'fountain; a person holding the greatest authority', aşçıbaşı 'head cook', ocakbaşı 'grillroom'.

Table 1- The noun compounds with $50 \%$ or more accurate recall ${ }^{1}$ :

\begin{tabular}{|c|c|}
\hline $\begin{array}{l}80-85 \% \\
\text { buzdolabl 'refrigerator' } \\
\text { ayakkabl 'shoes' } \\
\text { milletvekili 'member of parliament' } \\
\text { denizatt 'sea horse' }\end{array}$ & 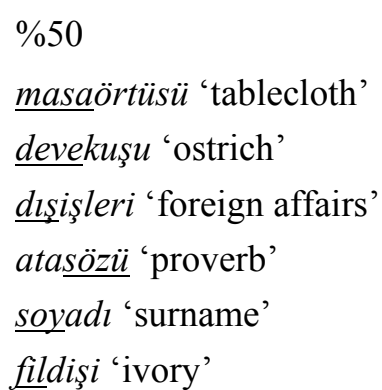 \\
\hline
\end{tabular}

\subsection{Results of Section B:}

This section was designed to avoid subjects from realizing the purpose of the questionnaire. As predicted, there were too many distinct answers in this section to be estimated. To illustrate with an item, when the head kitabl 'book' was provided 14 answers were given (only 10 had genitive suffix, 1 was ungrammatical, 3 of them unfilled) yllın kitabl 'book of the year', kizın kitabl 'the girl's book', adamin kitabl 'the man's book', Ahmet'in kitabl 'Ahmet's book', Ali'nin kitabl 'Ali's book', çocuğun kitabl 'the child's book', aşkın kitabl 'the book of love', hocanın kitabl 'the teacher's book', okulun kitabl 'the school's book', elalemin kitabl 'someone else's book'.

\subsection{Results of Section C:}

As can be seen from the following table, the proportion of recall of words written as two words were higher than that of words written as a single word. A total of 3 words reached $90-100 \%$ recall rate, 5 words reached $80-89 \%$ recall rate, 6 words reached $68-77 \%$ recall rate and one word reached $59 \%$ recall rate. In total, 15 words reached more than $50 \%$ recall rate.

2 The part that the subjects had to fill is underlined 
3 of the items reached $90-100 \%$ correct recall: su aygırl 'hippopotamus', şeker pancarl 'sugar beet', evlat actsl 'sorrow for children'. This is a very interesting point to note since this section required answers with words written apart. Especially, the recall of $\mathrm{acl}$ 'sorrow' when evlat 'child' is provided in the compound evlat acisl 'the sorrow for one's child' is noteworthy since this is not an entry found in dictionaries. This constitutes a perfect example of a cultural collocation. As defined in the previous section, collocations are frozen units conventionally used together. They come to signify certain aspects about culture through language. The meaning of these items are not transparent unless one is a native speaker. This is exactly the case with 'evlat actsl', which literally signifies 'the sorrow for one's child'; however, it came to refer only to the sorrow a parent feels when their child passes away.

As for the entry keçi 'goat', the participants gave one of two possible answers when the head keçi 'goat' was provided: dağ keçisi 'chamois', tiftik keçisi 'mohair goat'. When the head ışık 'light' was given, the answers were as follows: güneş ışı̆ğ

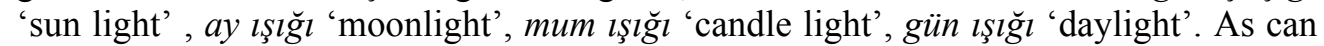
be observed, every participant gave one of these 4 answers. The same diversity of answers was observed when the modifier dağ 'mountain' was given in that there were 4 possible answers: dăg evi 'cottage', dăg başl 'mountain top', da $\breve{g}$ eteğ $i$ 'the skirt of a mountain', dağ yolu 'the road to the mountain'.

Table 2- The noun compounds with $50 \%$ or more accurate recall ${ }^{1}$ :

\begin{tabular}{|c|c|c|c|}
\hline 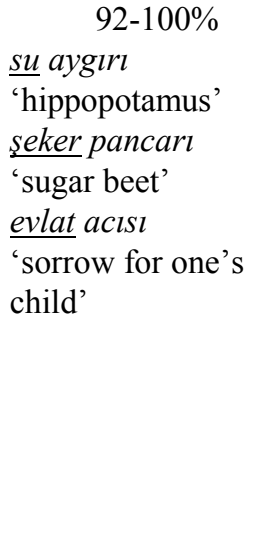 & $\begin{array}{l}\quad 80-89 \% \\
\text { yer elmast } \\
\text { 'jerusalem } \\
\text { artichoke' } \\
\text { bulgur pilave } \\
\text { 'bulghur rice' } \\
\text { tahin helvast } \\
\text { 'sesame oil halvah' } \\
\text { dil yarast } \\
\text { 'wounded feelings } \\
\text { caused by harsh } \\
\text { words' } \\
\text { bal mumu } \\
\text { 'bee's wax' }\end{array}$ & 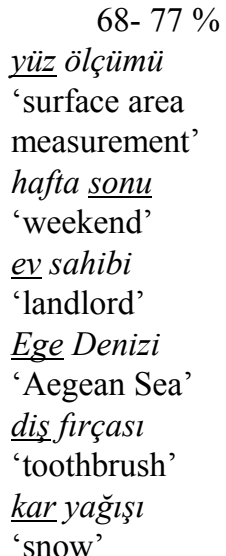 & $\begin{array}{l}\text { kapı kolu } \\
\text { 'door handle' }\end{array}$ \\
\hline
\end{tabular}

\subsection{Results of Section $A$ and $C$ compared}

These results from both section A \& $\mathrm{C}$ confirm that a large number of nominal compounds with $\mathrm{CM}$ in Turkish are treated as lexical items since the speakers store these compounds as one regardless of whether they are written as joint or apart. It

\footnotetext{
${ }^{3}$ The part that the subjects had to fill is underlined.
} 
should be noted at this point that in section $\mathrm{A}$ it has been stated that the head of the compound is the crucial element for the subjects to form the nominal compound. However, in section $\mathrm{C}$ most of the blanks filled by the subjects were the modifier parts of the compounds ( 8 out of 14) but they still constructed some lexicalized compounds that reached $90-100 \%$ recall rate. It might be suggested that in section $C$ the subjects might have felt more comfortable since they did not have to construct joint nominal compounds.

These findings also suggest that the participants did not treat the CM suffix as having a possessive interpretation. If they had done so, they would have written words with possessor/ possessed relation with the word given. However, they always placed a noun in such a way that the compound denoted an entity, as in buzdolabl 'refrigerator', ayakkabl 'shoes' or yer elmasl 'Jerusalem artichoke'. This demonstrates that the CM suffix -(s)I is functionally and semantically different from the third person possessive suffix denoting possession.

The distinction between the so-called 3PsPOSS and CM suffixes in noun compounds has also been discussed in previous studies (eg. Lewis, 1967; Schroeder, 1999; Banguoğlu, 1998; Underhill, 1976; Schaaik , 2001; Göksel and Kerslake, 2005). As Göksel and Kerslake (2005: 104) suggest: 'The function of the third person possessive suffix in -(s)I compounds is not to signify possession of one thing by another; it simply serves as a grammatical indicator of the compounding of the noun to which it is affixed with the immediately preceding noun.' As previously discussed, the results of the questionnaire also support this claim that -(s)I compounds do not denote possession. It simply functions as a mere grammatical element uniting two nouns which then act as a single lexical unit.

\section{5. Results of Section D:}

In this section, subjects were asked to choose one of the two identical nominal compounds differing only in the position of the adjective. They were told that they were not supposed to find which was correct but rather which one they used in daily language. The results can be observed from table 3 .

Table 3- The percentages of the items chosen by the participants: 


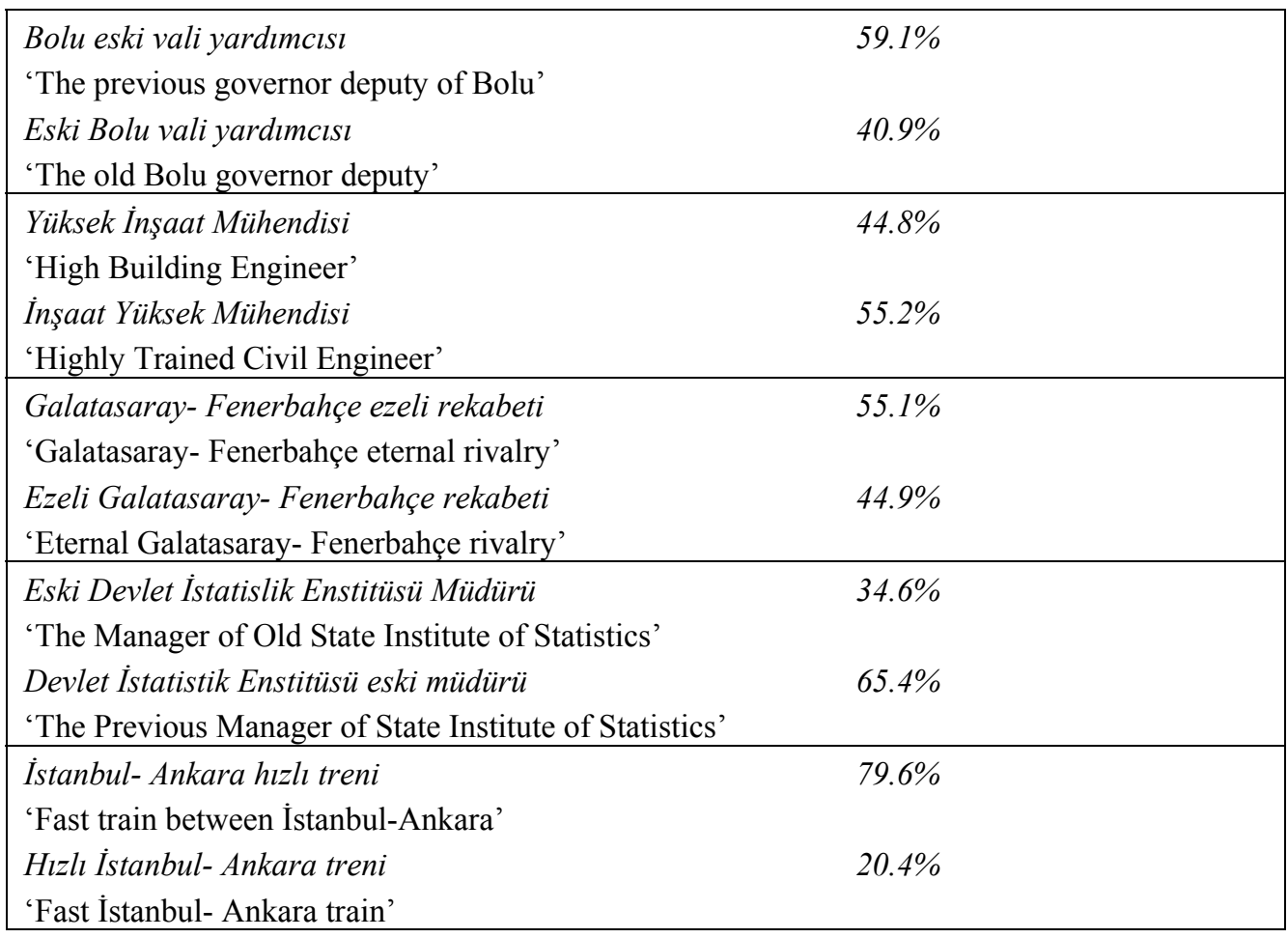

As Swift (1966 ctd. in Hayasi, 1996) puts forward, compounds with CM bear lexical characteristics; therefore, can be registered in the lexicon. Regarding compounds with $\mathrm{CM}$ as words results from the fact that though they consist of two separate lexical items, they denote only one lexical entity. This characteristic of the $\mathrm{CM}$-(s)I can further be proved by the fact that no other type of expression (e.g. an adjective) can interfere between a nominal compound with CM as can be seen from the following example:

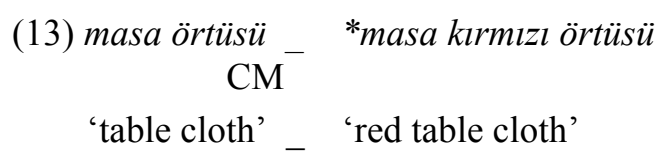

The same logic was employed in the preparation of the questionnaire. The subjects were supposed to find the item where the adjective did not interfere between the two 
elements of the compound. In the following examples from the questionnaire, acceptability of (b) is questionable when the rules about compound formation are considered since no adjective can break the compound. However, the acceptability of (a) is also questionable in the case where the scope of the adjective eski 'old' is only over devlet 'government'. If so, in that scope relation, the adjective does not modify müdür 'manager' but it can be interpreted as only modifying devlet 'state'.

a. ?Eski Devlet İstatistik Enstitüsü Müdürü \%34.6

'The Manager of Old State Institute of Statistics'

b. ?Devlet İstatistik Enstitüsü eski Müdürü \%65.3

'The Previous Manager of State Institute of Statistics'

When the adjective in example (a) and (b) is substituted by another adjective, as emektar 'faithful and long in service', then the questionability of the compound is still apparent:

\section{c. ?Emektar Devlet İstatistik Enstitüsü Müdürü}

\section{d. ?Devlet İstatistik Enstitüsü emektar Müdürü}

The items were selected due to their common use in everyday speech and by the media. So, although the forms are questionable as dictated by rules of grammar, more subjects picked them by convention. What is meant by convention is that, speakers are used to hearing such compound structures with the adjective breaking the compound so often that they regard them as acceptable. In spoken language these can be disambiguated by intonation, but since the questionnaire was in written format this was not possible.

If a compound with $\mathrm{CM}$ is to be modified by an adjective or other types of expression (e.g. a determiner), it has to precede the whole compound, not merely the head. The reason for this is that, the head combines first with the modifier noun, and then the adjective is attached to the whole compound:

\section{(14) kırmızı [masa örtüsü] *masa kırmızı örtüsü} 'red table cloth'

(15) bir [masa örtüsü] * masa bir örtüsü

a table cloth 
On the other hand, definite nominal compounds, known also as genitive-possessive constructions, do allow the interference of an adjective or a similar kind of expression between the components constituting the compound. The meaning changes according to the word the adjective modifies. In example (16) the tree is tall however in example (17) the branches are long:

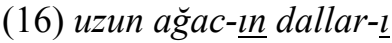
GEN 3PsPOSS

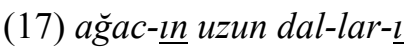
GEN 3PsPOSS 'the branches of the tall tree'

'the long branches of the tree'

At this point, it should be noted that the position of the adjective in genitivepossessive constructions is meaning-distinctive. If the adjective precedes the first constituent, it modifies only the first constituent and if it is between the constituents of the compound, it modifies only the second constituent. Therefore, it can be concluded that an adjective never modifies the whole compound in genitive-possessive constructions. This leads to the fact that genitive-possessive constructions do not bear a lexical status as compounds with CM.

As can be seen from the results, the numbers are very close to each other, therefore it is not possible to talk about a general preference. In each token, a larger number of the subjects chose the form where the adjective interfered between the noun compounds and modified only the head of the compound. However, the fact that a number of subjects chose the form where the adjective modifies the noun compound shows that both forms are permitted in the

language although the formation which does not allow the interference of an adjective between the compound is maintained by the rules of grammar.

\section{6. Results of Section E:}

In this section the participants were asked to circle those words which they think were lexicalized. However, this section was a little problematic. The majority of the subjects failed to answer this section. This may be due to the fact that they failed to read this question since it was in a more different format than the other questions where they had to fill in the blanks. They might have also chosen not to answer it since 
it was very time-consuming. Another reason may be that they found it difficult to tell which ones they would assume to be lexicalized. This is proven by the finding that some of them chose more than $80 \%$ of all words.

\section{DISCUSSION}

This study demonstrates that some indefinite nominal compounds bear lexical characteristics in Turkish. Our claim is that they form collocation and are thus inseperable. The use of one word of these nominal compounds, no matter whether it is the head or the modifier, triggers the recall of the other. They have frozen meanings which are not always the combination of the meanings of the words forming the compound, some meanings are not very predictable (e.g. gözaltı lit. 'under eye' 'custody'). The transparency of the meaning of the phrases is mostly available solely to native speakers. It can be claimed that they are stored in the lexicon as one unit as if they are one single word.

The outcome derives that whether written as one word or two words the nominal compounds with CM are frozen lexical forms in Turkish. Also revealed is that CM is semantically distinct from the possessive suffix -(s)I. CM does not encode possessive relation between the modifier and the head. CM solely marks the lexical relation between these two nouns making the compound. We can consider it as a glue for lexicalization of the noun compounds. The lexicalization is clearly seen in such words as ayakkabllar 'shoes', where the CM is no longer visible to morphology, since the plural follows the CM where normally it should precede the plural as in denizatlart 'sea horses'. In this respect, the results of the questionnare are in accordance with previous studies (e.g. Lewis, 1967; Schroeder, 1999; Banguoğlu, 1998; Underhill, 1976; Schaaik, 2001; Göksel and Kerslake, 2005).

Although adjectives cannot be inserted in between noun compounds, a number of subjects noted that they prefer to use this structure in compounds of 3 or more words. The authors' opinion is that this preference is due to the fact that they hear such structures in media often, and thus regard them as grammatical.

One of the limitations about the study is based on the property of nominal compounds in Turkish. There has always been a dispute about whether noun compounds as evkadını 'housewife', yasadışı 'illegal' or zeytinyağ $\breve{l}$ 'olive oil' are written as one word or two words. The subjects reported that they were not able to decide whether the compounds they would construct were written as one word or two words. 
The framework of this study may be used to guide future research towards comparing the different formations of nominal compounds across languages, finding out whether the same operational rules are being employed, or the same lexicalization process is apparent.

\section{REFERENCES}

Banguoğlu, Tahsin. 1998. Türkçenin Grameri. Ankara: Ankara Üniversitesi Basımevi.

Göksel, Asl1; Celia, Kerslake. 2005. Turkish: A Comprehensive Grammar. London:

Routledge.

Gencan, Tahir, N. 1979. Dilbilgisi. Ankara: Ankara Üniversitesi Basımevi.

Hayasi, Tooru. 1996. The Dual Status of Possessive Compounds in Modern Turkish.

Symbolae Turcologicae. Studies in honor of Lars Johanson on the occasion of his Sixtieth Birthday, March 8, 1996. Vol 6.A. Berta, B. Brendemoen \& C. Shönig (eds.). İstanbul: Swedish Research Institute in İstanbul - Transactions.

Kornfilt, Jaklin. 1997. Turkish. London and New York: Routledge

Lewis, Geoffrey, L. 1967. Turkish Grammar. Oxford - New York: Oxford University Press

McCarthy and O'Dell, 2002. English Vocabulary in Use: advanced. Cambridge: Cambridge University Press.

Schaaik, van Gerjan. 2001. Higher Order Compounds in Turkish. The Bosphorus Papers:

Studies in Turkish Grammar 1996-1999. İstanbul: Boğaziçi University Press

Schroeder, Christoph. 1999. The Turkish Nominal Phrase in Spoken Discourse. Wiesbaden:

Harrassowitz

Swift, Lloyd, B. 1963. A Reference Grammar of Modern Turkish. Bloomington: Indiana University

Underhill, Robert. 1976. Turkish Grammar. Cambridge-London: MIT Press

\section{Appendix A:}

$\begin{array}{llll}\text { Yaş: } & \text { Cinsiyet: } & \text { Kız ( ) } & \text { Erkek ( ) } \\ \text { Eğitim: } & \text { İlköğretim ( ) } & \text { Lise ( ) } & \text { Üniversite ( ) }\end{array}$

A) Verilen örnek doğrultusunda, aşağıda verilen boşlukları uygun olan 'tamlayan' ya da 'tamlanan' kelimelerle doldurarak 'bileşik yazılan' isim tamlamaları oluşturunuz.(Boşluklara birden çok kelime yazılabilir. Siz uygun olduğunu düşündüğünüz bir tanesini yazınız.)

Örnek: eti _ dişeti

kireç kireçtaşı 
1.

2. ata

3.
4. göz
5. burnu
6. dolab1
7. dağ
8. deve
9. gök
10.
baș1

11.

12. boyun

13. bilgisi

14. misir

15. el

16. çekimi

17. vekili

18. kavun

19.

20.

diși

işleri
21. ates

22.

$23 . \quad$ evi

24. eșek

25.

$26 . \quad \mathrm{ad} 1$

27. kamu

28. diș1

29. topu

30. kus

B) Verilen örnek doğrultusunda, aşağıdaki boşluklardan uygun olan yerlere 'tamlayan' ya da 'tamlanan' kelimeler getirerek belirtili isim tamlamaları oluşturunuz. (Belirtili isim tamlamaları her iki kelimenin de takı aldığı tamlamalardır.)

\begin{tabular}{|c|c|c|}
\hline Örnek: kitabın & kitabı sayfası & $\ldots_{\text {anahtarı _ arabanın anahtarı }}$ \\
\hline 1. evin & 6 & kitab1 \\
\hline 2. __ rengi & 7. olayın & \\
\hline 3. ___ düğmesi & 8. & kolu \\
\hline 4. çantanın & 9. & tad1 \\
\hline 5. sokağın & 10. ağacın & \\
\hline
\end{tabular}

C) Verilen örneğe bakarak aşağıda verilen boşlukları uygun 'tamlayan' ya da 'tamlanan kelimelerle doldurarak birer belirtisiz isim tamlaması oluşturunuz. Belirtisiz isim tamlamaları yalnızca 'tamlayan'ın yani birinci kelimenin takı aldığı tamlamalardır. Burada oluşturacağınız tamlamalardaki kelimeler ayrı yazılmalıdır.

Örnek: okul _okul kapısı bahçesi _ çay bahçesi

1.

2. aygır1

3. sağlik

4. kurusu kardeşi

5. elmas1

6. kedisi

7. bulgur
11.__ aris1

12. ___ firçası

13. evlat

14. dil

15. yolcu

16. kadını

17. ders
21.

22. denizi

23. dağ

24. kap1

25. ölçümü

26. mumu

27. hafta 
8. pancar1

9. borcu

10. tahin
18. çam

19.

20 yağış1

elmas1
28.

29. calı

30. keçisi

D) Aşağıda verilen isim tamlaması çiftlerinden hangisini günlük dilinizde kullanmayı tercih edersiniz? Seçtiğiniz tamlamanın yanındaki boşluğa $(\mathrm{x})$ işareti koyunuz.

1. Bolu eski vali yardımcısı ( ) / Eski Bolu vali yardımcısı ( )

2. Yüksek İnşaat Mühendisi( ) / İnşaat Yüksek Mühendisi ( )

3. Galatasaray-Fenerbahçe ezeli rekabeti ( ) / Ezeli Galatasaray-Fenerbahçe rekabeti ( )

4. Eski Devlet İstatistik Enstitüsü müdürü ( ) / Devlet İstatistik Enstitüsü eski müdürü ( )

5. İstanbul-Ankara hızlı treni ( ) / Hızlı İstanbul-Ankara treni ( )

E) Son olarak anketin $\mathbf{A}$ ve $\mathbf{C}$ bölümlerinde kurduğunuz isim tamlamalarına tekrar bir göz atınız. Sizce bu tamlamalardan hangileri bir nesneyi ya da kavramı karşılayan tek bir kelime haline gelmiştir? Tek bir kelime haline geldiğini düşündüğünüz tamlamaların yanlarındaki numaraları yuvarlak içine alınız. 